Kong. Res. J. 2(2) : 72-83, 2015

ISSN 2349-2694

Kongunadu Arts and Science College, Coimbatore.

\title{
UTILIZATION AND CONSERVATION OF FLORA IN THE HOME GARDENS OF SOME RESIDENTIAL AREAS, COIMBATORE
}

\author{
Karthika, K., R. Subhasree, S. Jamuna and S. Paulsamy* \\ PG and Research Department of Botany, Kongunadu Arts and Science College, Coimbatore. \\ *E.mail: paulsami@yahoo.com
}

\begin{abstract}
Home garden can serve as an important source of both food and cash income for vulnerable households. The objectives of this study were to documenting the flora of the home gardens, obtaining their frequency and to categorize the plants into medicinal/other economically important species according to their utility value in 10 different residential areas of Coimbatore city. The home garden surveys revealed that totally 90 species, were enlisted in the sampled areas and of them the higher species richness of 26 were found in Vadavalli residential area. Overall 47 families were recorded, among them Acanthaceae and Apocyanaceae were more dominant families in the study sites. In the species content 72 were recognized as medicinally important and 18 as ornamental. It was further known that the residents of middle class earned sizeable income through vegetables in addition to fulfilling their day to day need while the residents of upper class highly preferring ornamental species. Few species like Saraca indica, the endemics are well protected by cultivation in homegardens. Thus the present study presumes that home gardens satisfy various household needs and conserve medicinally valuable species.
\end{abstract}

Keywords: Home gardens, residential areas, Coimbatore, frequency.

\section{INTRODUCTION}

Home gardens are species-rich agroforestry systems maintained on the basis of choice, needs and importance of plants. It is a traditional land use practice around a homestead where several plant species are maintained by members of the house hold and their products are intended to be an economically consumption (Shrestha et al., 2001). Compared to other agricultural or horticultural ecosystems, home gardens are having rich species content and well suited for ex situ conservation of many rare/endangered species, besides fruit and timber trees. Home garden structure also varies from place to place according to the local physical environment, ecological characteristics, socioeconomic and cultural factors (Abdoellah, 1990; Kumar and Nair, 2004).

Coimbatore is the leading industrial city in southern India. The industrial areas, educational institutions and residential areas are maintaining home gardens almost in all parts of the city. Generally, greens and other vegetable crops are maintained to meet the demand of day to day life. However, many upper economic class people and educated people maintained their home gardens with many ornamental plants and some plants of red listed categories also. Despite the well establishment of home gardens no taxonomical and ecological studies have been made so far in Coimbatore city. To address this lacuna, the present study has been carried out in 10 houses which spread all over the Coimbatore city in different locations and aimed to document the flora of the home gardens, calculating their frequency and to categorize the plants based on their utility value.

\section{MATERIALS AND METHODS}

\subsection{Sampling places}

A total number of 10 home gardens with different sizes located in the places viz., R.S. Puram, Race course, G.N. Mills, Viswasapuram, Ganapathy, Vadavalli, Manikarapalayam, Mettupalayam, Nava India and Saravanampatti were selected for the present study in Coimbatore city. The home gardens selected were explored for the plant species for the informations on habit, family, parts used and medicinal/other economic uses. The degree of distribution of various plant species among the home gardens was determined as per the following formula:

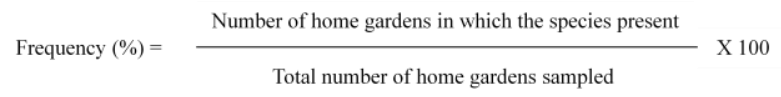

The medicinal and other economic uses of the plant species present in the home gardens of sampling places were documented on the basis of 
personal interview with the respective gardener of the institutions, local public and the owners of the residential homes and by available literature. The red listed and endemic plants were enlisted according to Ahmedullah and Nair (1987).

\section{RESULTS AND DISCUSSION}

For the present study, all over the city of Coimbatore, 10 home gardens in 10 different residential areas have been selected to enumerate the species taxonomically and to evaluate ecologically (Table 1 and Fig. 1). The sizes of the home gardens sampled were also varied much between ca. $25 \mathrm{~m}^{2}$ and $225 \mathrm{~m}^{2}$. In this range most of the home gardens were within the global inventory range of other tropical home gardens (Fernandez and Nair, 1986). The number of species and their numerical strength were not in accordance with the size of the home gardens studied in Coimbatore city. Studies of home gardens in Mexico (Rico Gray et al., 1991) and Indonesia (Abdoellah et al., 2006) indicated that the number of species or individuals is not related to home garden size. The species richness was noted to be varied between the home gardens studied. The higher species richness of 26 was present in the home garden of Vadavalli residential area. On the other hand, the lower species richness of 11 was noted in the residential areas of R.S. Puram.

Altogether, 90 plant species belongs to different life forms were noted to be present in the studied home gardens. A higher number of 46 species $(51.1 \%)$ were in the form of herbs followed by the shrubs with 26 species (28.9\%), trees with 14 species $(15.6 \%)$ and climbers with 4 species (4.4\%) (Table 1). This may be due to the need and individual option. The most grown herbs in the gardens are mainly for the purpose of supplying requirements to their day to day life as vegetables, greens and medicinal plants.

In addition to higher species diversity, the diversity of families was noted to be most noteworthy (Table 2). A total number of 47 families with the contribution of 90 species were present in the home gardens. The family, Acanthaceae contributed the higher number of 7 species (7.8\%) followed by the family, Apocyanaceae with 6 species $(6.7 \%)$ and Asteraceae, Amaranthaceae and Solanaceae with 5 species $(5.6 \%)$ each to the communities of home gardens. The remaining families have contributed 1,2 or 3 species only to home garden communities. It indicates the diverse utility of the plant resources particularly the preferences towards medicinal uses (Kumar et al., 1994). The high floristic diversity is perhaps the reflection of the potential of home gardens to serve as repositories of genetic diversity as well (Esquivel and Hammer, 1992). Kabir and Webb (2008) also reported the predominance of herbs and trees in the home gardens of south western Bangladesh.

The degree of distribution of the various enumerated plant species was very low and it was ranging between 10 and $50 \%$ only (Table 1 ). The species namely, Adenium obesum, Anthurium spathyiphyllum, Aloe vera, Ficus benjamina, Plumbago auriculata and Plumeria rubra have registered 50\% frequency which indicates that these species have distributed comparatively in higher number of home gardens (Fig. 2). Other species have recorded below $50 \%$ frequency and hence these species have restricted distribution in few home gardens only. The total number of individuals maintained for the constituent species in the home gardens was widely varied (Table 1 and Figs. 3 and 4). Pandey et al. (2006) also reported the lower distribution level of many home garden plants in South Andaman and he explained that the selective cultivation of species with the home gardens is mainly due to the utility value of the species. The endemic plant species, Saraca indica was represented by only one individual at Ganapathy residential area. It ensures the expansion of the geographical area for this species. Similarly, the species such as Artocarpus heterophyllus, Dracaena sp., Ficus benghalensis, Hamelia patens, Jasminum grandiflorum, J. sambac, Momordica charantia, Musa paradisiaca, Sansevieria roxburghiana, Saraca indica, Thunbergia mysorensis and Taxus wallichiana have also been represented by only one individual (Fig. 4).

The economic importance including the medicinal uses of the various plant species present in the sampled home gardens of Coimbatore city is presented in Table 2. In the account of 90 species, 72 $(80 \%)$ were recognized as medicinally important and $18(20 \%)$ as ornamentals. The medicinal uses of the plant species are multidimensional. A greater number of 16 species are used to treat inflammation related diseases, 13 species prescribed for skin problems, 10 species are suggested for diabetics and 8 species are used for anticancer. Ecological and socioeconomic factors, including geographic location, climate, water availability, garden size and history, agricultural policy, market needs, food cultivars and house hold preferences influence the species diversity and utilization of the product of traditional home gardens (Gajaseni and Gajaseni, 1999; Trinh et al., 2003). 
Table 1. Number of individuals of constituent plant species and their frequency in the sampled home gardens of Coimbatore city.

\begin{tabular}{|c|c|c|c|c|c|c|c|c|c|c|c|c|c|}
\hline \multirow{2}{*}{ S.No. } & \multirow{2}{*}{ Name of the species } & \multirow{2}{*}{ Habit } & \multicolumn{10}{|c|}{ Home gardens* } & \multirow{2}{*}{$\begin{array}{c}\text { Frequency } \\
\text { (\%) }\end{array}$} \\
\hline & & & 1 & 2 & 3 & 4 & 5 & 6 & 7 & 8 & 9 & 10 & \\
\hline 1. & Acalypha wilkesiana Hort. & Shrub & - & - & - & - & - & - & 10 & - & - & - & 10 \\
\hline 2. & Adenium obesum (Forsk.) Roem. et Schult. & Shrub & - & 2 & - & - & 3 & 4 & - & 5 & - & 3 & 50 \\
\hline 3. & Anthurium spathiphyllum Schott. & Herb & - & - & 3 & 5 & 3 & 2 & 3 & - & - & - & 50 \\
\hline 4. & Allamanda cathartica L. & Shrub & - & 2 & - & - & & - & 3 & - & - & - & 20 \\
\hline 5. & Aloe vera (L.) Burm.f. & Succulent herb & 2 & 5 & 6 & 4 & - & - & 3 & - & - & - & 50 \\
\hline 6. & Aphelandra squarrosa Nees. & Herb & - & - & - & - & - & - & 7 & - & - & - & 10 \\
\hline 7. & Aralia sp. L. & Herb & - & - & - & - & - & - & - & 5 & - & - & 10 \\
\hline 8. & Arcotis frutescens $\mathrm{L}$. & Shrub & - & - & - & - & 6 & - & - & - & - & - & 10 \\
\hline 9. & Arctotis hirsuta (Harv.) Beauverd. & Herb & - & - & - & - & - & - & - & - & - & 12 & 10 \\
\hline 10. & Argyranthemum frutescens $\mathrm{L}$. & Herb & - & - & - & - & 94 & - & - & - & - & - & 10 \\
\hline 11. & Araucaria excelsa R.Br. & Tree & - & - & - & - & - & - & 3 & - & - & - & 10 \\
\hline 12. & Achyranthes aspera L. & Herb & - & - & 20 & - & - & - & - & 15 & - & - & 20 \\
\hline 13. & Amaranthus spinosus L. & Herb & - & - & - & - & - & - & - & 34 & - & - & 10 \\
\hline 14. & A. caudatus L. & Herb & - & - & - & - & - & - & - & 31 & - & - & 10 \\
\hline 15. & Azardica indica A. Juss. & Tree & - & - & - & - & - & 1 & - & - & - & 1 & 20 \\
\hline 16. & Artocarpus heterophyllus Frost. & Tree & - & - & - & - & - & 1 & - & - & - & - & 10 \\
\hline 17. & Barleria grandis Hochst. ex Nees. & Herb & - & - & - & - & - & - & - & - & 12 & - & 10 \\
\hline 18. & Bougainvillea glabra Choisy. & Creeper & - & - & - & 6 & - & - & - & - & - & - & 10 \\
\hline 19. & Callistemon citrinus (Curtis) Skeels. & Shrub & - & - & - & 2 & - & - & - & - & - & - & 10 \\
\hline 20. & Calliandra cyanometroides Bedd. & Herb & 17 & - & - & - & - & - & - & 12 & - & - & 20 \\
\hline 21. & Campsis radicans Seem. & Herb & - & - & 12 & 9 & - & - & - & - & - & - & 20 \\
\hline 22. & Capsicum annuum L. & Shrub & - & - & - & 5 & - & - & - & - & - & - & 10 \\
\hline 23. & Catharanthus roseus L. & Sub shrub & - & 21 & - & - & - & - & 14 & - & - & - & 20 \\
\hline 24. & Celosia cristata $\mathrm{L}$. & Shrub & - & - & - & - & - & 5 & - & - & - & 1 & 20 \\
\hline 25. & Cereus pterogonus Lem. & Herb & - & - & - & - & - & 4 & - & - & - & - & 10 \\
\hline 26. & Cestrum nocturnum L. & Herb & - & 50 & 43 & - & - & - & - & - & - & - & 20 \\
\hline 27. & Chlorophytum variegatum Ker. & Herb & - & - & 2 & - & 1 & 2 & - & - & 8 & - & 40 \\
\hline 28. & Chrysanthemum carinatum L. & Herb & - & - & - & - & - & - & 6 & - & - & 3 & 20 \\
\hline 29. & C. odoratum L. & Herb & - & - & 64 & 82 & - & - & - & - & - & 41 & 30 \\
\hline 30. & Clitoria ternatea $\mathrm{L}$. & Herb & - & - & - & - & 19 & - & - & - & - & - & 10 \\
\hline 31. & Clerodendrum thomsoniae Balf. & Shrub & - & - & - & - & - & 5 & - & - & - & - & 10 \\
\hline
\end{tabular}




\begin{tabular}{|c|c|c|c|c|c|c|c|c|c|c|c|c|c|}
\hline 32. & Coleus aromaticus Benth. & Herb & - & - & - & - & - & 15 & 12 & 5 & - & - & 30 \\
\hline 33. & Cordyline stricta $\mathrm{L}$. & Herb & - & - & 5 & - & - & - & - & - & - & - & 10 \\
\hline 34. & Cosmos bipinnatus Cav. & Herb & - & - & 74 & - & - & - & 50 & - & - & - & 20 \\
\hline 35. & Crassula sp. L. & Herb & - & - & - & - & - & - & 10 & - & 13 & 5 & 30 \\
\hline 36. & Crossandra infundibuliformis L. Salib. & Herb & - & - & - & - & - & - & - & - & - & 10 & 10 \\
\hline 37. & Cucumis pepo DC. & Climber & - & - & - & - & - & 5 & - & - & - & - & 10 \\
\hline 38. & Curcuma longa L. & Herb & - & 3 & - & - & - & 3 & - & - & - & 5 & 30 \\
\hline 39. & Calotropis gigantea $\mathrm{R} . \mathrm{Br}$. & Shrub & 2 & - & - & - & - & - & - & 1 & - & - & 20 \\
\hline 40. & Carica papaya L. & Tree & - & - & - & 1 & - & - & - & 1 & - & - & 20 \\
\hline 41. & Coriandrum sativum L. & Herb & - & - & 24 & - & - & - & - & - & - & - & 10 \\
\hline 42. & Cardiospermum halicacabum L. & Herb & - & 3 & - & - & - & - & - & - & - & - & 10 \\
\hline 43. & Cycas siamensis Miq. & Tree & - & - & - & - & - & 2 & - & - & - & 1 & 20 \\
\hline 44. & Dracaena sp. Lam. & Shrub & 1 & - & - & - & - & - & - & - & - & - & 10 \\
\hline 45. & Duranta repens L. & Shrub & - & - & - & - & 2 & - & - & - & - & - & 10 \\
\hline 46. & Damascus carota Nayeem Ket. & Herb & - & - & - & - & 11 & 6 & 3 & - & - & - & 30 \\
\hline 47. & Euphorbia pulcherrima Willd. ex Klotz. & Shrub & - & 10 & - & - & - & - & - & - & - & - & 10 \\
\hline 48. & Ficus benghalensis L. & Tree & - & 1 & - & - & - & - & - & - & - & - & 10 \\
\hline 49. & F. benjamina $\mathrm{L}$. & Tree & 6 & - & - & 8 & 4 & 2 & - & - & - & 2 & 50 \\
\hline 50. & F. microspora Wight. & Tree & - & 2 & - & - & - & - & - & - & 2 & 4 & 30 \\
\hline 51. & Geranium domesticum Roxb. & Herb & 9 & - & - & - & - & - & - & - & - & - & 10 \\
\hline 52. & Gomphrena globosa Jacq. & Herb & 105 & 95 & - & - & - & - & - & - & - & - & 20 \\
\hline 53. & Grevillea robusta A. Cunn. ex R.Br. & Shrub & - & - & - & - & 4 & 2 & - & - & - & - & 20 \\
\hline 54. & Hamelia patens Jacq. & Shrub & - & - & - & - & 1 & - & - & - & - & - & 10 \\
\hline 55. & Hibiscus rosa sinensis L. & Shrub & - & - & - & - & 2 & 1 & - & - & 5 & - & 30 \\
\hline 56. & H. syriacus L. & Shrub & - & 1 & - & 1 & - & - & - & - & - & - & 20 \\
\hline 57. & Inga cyanocetroides $\mathrm{L}$. & Shrub & 1 & - & - & - & - & 2 & - & - & - & 2 & 30 \\
\hline 58. & Ixora coccinea $\mathrm{L}$. & Shrub & - & - & 2 & - & - & - & - & - & - & - & 10 \\
\hline 59. & Jacquemontia pentantha Choisy. & Herb & - & - & 29 & - & 48 & - & - & - & - & - & 20 \\
\hline 60. & Jasminum grandiflorum L. & Herb & 1 & - & - & - & - & - & - & - & - & - & 10 \\
\hline 61. & J. sambac Ait. & Herb & - & - & - & - & - & - & - & 1 & - & - & 10 \\
\hline 62. & Kalanchoe fentchokoi Adans. & Herb & - & - & - & - & - & - & - & - & - & 10 & 10 \\
\hline 63. & Lablab purpureus (L) Sweet. & Vine & - & - & - & 2 & 8 & - & - & - & 4 & 3 & 40 \\
\hline 64. & Lawsonia inermis $\mathrm{L}$. & Tree & - & - & - & - & - & 1 & 1 & - & - & - & 20 \\
\hline 65. & Mangifera indica $\mathrm{L}$. & Tree & - & - & - & - & - & 1 & - & - & 1 & - & 20 \\
\hline 66. & Miranda leucophyllum Harts. & Tree & - & - & 12 & - & - & - & - & - & - & - & 10 \\
\hline 67. & Momordica charantia L. & Herb & - & - & - & - & 1 & - & - & - & - & - & 10 \\
\hline
\end{tabular}




\begin{tabular}{|c|c|c|c|c|c|c|c|c|c|c|c|c|c|}
\hline 68. & Musa paradisiaca L. & Tree & - & 1 & - & - & - & - & - & - & - & - & 10 \\
\hline 69. & Nephrolepis sp. Schot. & Herb & - & - & - & - & - & - & - & 8 & - & - & 10 \\
\hline 70. & N. tuberosa Bory ex Willd. & Herb & 1 & - & - & - & - & - & - & - & - & 1 & 20 \\
\hline 71. & Nerium oleander L. & Shrub & - & - & - & - & 1 & - & 2 & - & - & - & 20 \\
\hline 72. & Nymphaea pubescens Wild. & Succulent herb & 5 & 3 & - & - & 2 & - & - & - & - & - & 30 \\
\hline 73. & Ocimum basilicum L. & Herb & - & - & - & - & - & - & - & - & 4 & - & 10 \\
\hline 74. & Plumbago auriculata Lam. & Herb & 2 & - & - & - & - & 2 & 2 & - & 11 & 3 & 50 \\
\hline 75. & Plumeria rubra L. & Shrub & - & 1 & - & 2 & - & 1 & 1 & - & 1 & - & 50 \\
\hline 76. & Piper betle L. & Creeper & - & - & - & - & - & - & 38 & - & - & - & 10 \\
\hline 77. & Ravenala madagascariensis Sonn. & Herb & - & - & 1 & - & - & - & - & - & - & 1 & 20 \\
\hline 78. & Rosa sp.W. & Shrub & - & - & - & 3 & - & - & - & - & - & 4 & 20 \\
\hline 79. & Salvinia officinalis L. & Herb & - & - & - & - & - & 2 & - & - & 1 & - & 20 \\
\hline 80. & Sansevieria roxburghiana Schult. & Herb & - & 1 & - & - & - & - & - & - & - & - & 10 \\
\hline 81. & Solanum xanthocarpum Sch and wend. & Herb & 2 & 3 & - & - & - & - & - & - & - & - & 20 \\
\hline 82. & S. melongena $\mathrm{Pr}$. & Herb & - & - & - & 2 & - & - & - & - & - & - & 10 \\
\hline 83. & S. lycopersicum L. & Herb & - & - & - & - & 3 & - & - & - & - & - & 10 \\
\hline 84. & Saraca indica $\mathrm{L}$. & Tree & - & - & - & - & 1 & - & - & - & - & - & 10 \\
\hline 85. & Thuja occidentalis L. & Shrub & - & - & - & - & 2 & - & 3 & 2 & 1 & - & 40 \\
\hline 86. & Thunbergia erecta Roxb. & Shrub & - & - & - & - & - & 10 & - & - & - & - & 10 \\
\hline 87. & T. mysorensis T.and Roxb. & Shrub & - & - & - & - & - & 1 & - & - & - & - & 10 \\
\hline 88. & Tabernaemontana divaricata R.Br. ex Roem. \& Schult. & Shrub & - & - & - & - & - & 1 & - & 2 & - & - & 20 \\
\hline 89. & Taxus wallichiana $\mathrm{L}$. & Tree & - & - & - & - & - & - & - & 1 & - & - & 10 \\
\hline 90. & Zephyranthes carinata L. & Herb & - & - & - & - & - & 16 & - & - & - & - & 10 \\
\hline
\end{tabular}

*1. R.S. Puram; 2. Race course; 3. G.N. Mills; 4. Viswasapuram; 5. Ganapathy; 6. Vadavalli; 7. Manikarapalayam; 8. Mettupalayam; 9. Nava India; 10. Saravanampatti.

Table 2. The included family useful part, medicinal and other economic uses of various plant species in the home gardens of Coimbatore city.

\begin{tabular}{|c|c|c|c|c|}
\hline S.No. & $\begin{array}{l}\text { Name of the } \\
\text { species }\end{array}$ & Family & Parts used & Medicinal/Other economic uses \\
\hline 1. & Acalypha wilkesiana & Acanthaceae & Leaf & $\begin{array}{l}\text { The extract of the flower inhibits the ovarian function and stimulate the uterine. } \\
\text { Roots are used in the treatment of diabetics, antipyretic, abortifacient, demulcent } \\
\text { and useful to relieve chest pain. }\end{array}$ \\
\hline 2. & Adenium obesum & Apocynaceae & $\begin{array}{l}\text { Bark and } \\
\quad \text { sap }\end{array}$ & $\begin{array}{l}\text { The plant sap and bark are used as remedy for bone dislocation, rheumatism, } \\
\text { sprains, paralysis, swellings and skin infections. }\end{array}$ \\
\hline 3. & $\begin{array}{l}\text { Anthurium } \\
\text { spathiphyllum }\end{array}$ & Araceae & Whole plant & $\begin{array}{l}\text { Cleans indoor air of many environmental contaminants, including benzene, } \\
\text { formaldehyde and other pollutants. }\end{array}$ \\
\hline 4. & Allamanda & Apocynaceae & Flower & Flower has been used to treat liver tumors, jaundice, splenomegaly and malaria. \\
\hline
\end{tabular}




\begin{tabular}{|c|c|c|c|c|}
\hline & cathartica & & & \\
\hline 5. & Aloe vera & Liliaceae & Leaf & $\begin{array}{l}\text { It is a remedy for coughs, wounds, ulcers, gastritis, diabetics, cancer, arthritis, } \\
\text { immune-system deficiencies and many other conditions when taken internally. }\end{array}$ \\
\hline 6. & $\begin{array}{l}\text { Aphelandra } \\
\text { squarrosa }\end{array}$ & Acanthaceae & - & Ornamental plant \\
\hline 7 & Aralia sp. & Araliaceae & - & Ornamental plant \\
\hline 8. & Arcotis frutescens & Asteraceae & Whole plant & Plants used to treat of opportunistic fungal infections in HIV/AIDS patients. \\
\hline $\begin{array}{l}8 . \\
9\end{array}$ & Arctotis hirsuta & Acanthaceae & - & Ornamental plant \\
\hline 10. & $\begin{array}{l}\text { Argyranthemum } \\
\text { frutescens }\end{array}$ & Asteraceae & $\begin{array}{c}\text { Flower and } \\
\text { leaf }\end{array}$ & $\begin{array}{l}\text { Flower in tonics as an ophthalmic and purgative, fresh or dried flowering heads are } \\
\text { normally used in the treatment of rheumatism, arthritis, liver and kidney } \\
\text { disorders, as a blood purifier, etc. Daisy leaves cures mouth ulcers. }\end{array}$ \\
\hline 11 & Araucaria excelsa & Araucariaceae & Leaf & It reduces the bacterial contaminants. \\
\hline 12. & Achyranthes aspera & Amaranthaceae & $\begin{array}{l}\text { Leaf and } \\
\text { seed }\end{array}$ & $\begin{array}{l}\text { It is used to improve appetite and to cure various types of gastric disorders. It is } \\
\text { useful in haemorrhoids. Leaves and seeds are emetic, hydrophobia, carminative, } \\
\text { resolve swelling, digestive and expel phlegm. }\end{array}$ \\
\hline 13. & Amaranthus spinosus & Amaranthaceae & Leaf & $\begin{array}{l}\text { Plant is used as a digestive, laxative, diuretic, stomachic, antipyretic, to improve } \\
\text { appetite, biliousness, blood diseases, burning sensation, leprosy, bronchitis, piles } \\
\text { and leucorrhea. The boiled leaves and root are given to children as a laxative. }\end{array}$ \\
\hline 14. & A. caudatus & Amaranthaceae & $\begin{array}{l}\text { Leaf, stem } \\
\text { and root }\end{array}$ & $\begin{array}{l}\text { The roots are used to cure kidney stones. The leaves used to cure cuts, leprosy, } \\
\text { boils, burns and fever. Decoction of the stem used to treat jaundice. } \\
\text { Leaves, bark, flowers, fruits, seed, gum, oil and neem cake are used to have }\end{array}$ \\
\hline 15. & $\begin{array}{l}\text { Artocarpus } \\
\text { heterophyllus }\end{array}$ & Meliaceae & Whole plant & $\begin{array}{l}\text { antiallergenic, antidermatic, antifeedent, antifungal, antiinflammatory, } \\
\text { antipyorrhoeic, antiscabic, cardiac, diuretic, insecticidal, larvicidal, nematicidal, } \\
\text { spermicidal and other biological activities. }\end{array}$ \\
\hline 16. & Azardirachta indica & Moraceae & $\begin{array}{l}\text { Leaf and } \\
\text { fruit }\end{array}$ & $\begin{array}{l}\text { The leaves are useful in fever, ulcers, boils, wounds, skin diseases, antidiarrhoeal, } \\
\text { analgesic and as immuno modulator. The ripe fruits are sweet cooling, laxative, } \\
\text { aphrodisiac and tonic. The seeds used for diuretic, aphrodisiac and constipation. }\end{array}$ \\
\hline 17. & Barleria grandis & Acanthaceae & Leaf & $\begin{array}{l}\text { Leaf extract treats for hepatic disorders, gastrointestinal disorders, skin disorders, } \\
\text { snake bites, cuts and wounds, sexually transmitted diseases, pain, fever, } \\
\text { respiratory tract disorders, paralysis, diabetics, rheumatoid arthritis, impotency } \\
\text { and bone fractures. }\end{array}$ \\
\hline 18. & Bougainvillea glabra & Nyctaginaceae & Flower & $\begin{array}{l}\text { The leaves used for a variety of disorders such as diarrhoea, stomach ulcers, cough } \\
\text { and hepatitis. A decoction of dried stems and flowers used as treatment for low } \\
\text { blood pressure. }\end{array}$ \\
\hline 19. & Callistemon citrinus & Myrtaceae & Leaf & It is used to treat hemorrhoids. \\
\hline & cyanometroides & Myrtaceae & & Ornamental plant \\
\hline 21. & Campsis radicans & Bignoniaceae & Leaf & $\begin{array}{l}\text { Leaf extract having antiinflammatory, antibacterial and antifungal properties. It is } \\
\text { used as syrups, infusions, typhoid, anaemia, malaria and headache. }\end{array}$ \\
\hline
\end{tabular}




\begin{tabular}{|c|c|c|c|c|}
\hline 22. & Capsicum annuum & Solanaceae & Fruit & $\begin{array}{l}\text { It is used as carminative, appetizer and cure stomachic. Externally, it is used as a } \\
\text { counter irritant and also in the treatment of rheumatism and neuralgia. }\end{array}$ \\
\hline 23. & Catharanthus roseus & Apocynaceae & Whole plant & $\begin{array}{l}\text { Minimizing the adverse effects of chemotherapy, caricinogenic agents and controls } \\
\text { bacterial, fungal and viral infections. }\end{array}$ \\
\hline 24. & Celosia cristata & Amaranthaceae & $\begin{array}{l}\text { Leaf flower } \\
\text { and seed }\end{array}$ & $\begin{array}{l}\text { It is used for the treatment of diarrhoea, piles, bleeding nose, disinfectant, } \\
\text { inflammation, haematological and gynaecologic disorders. }\end{array}$ \\
\hline 25. & Cereus pterogonus & Cactaceae & & Ornamental plant \\
\hline 26. & Cestrum nocturnum & Solanaceae & Leaf & $\begin{array}{l}\text { Leaves are used for their pharmacological significance in burns and swellings. It is } \\
\text { also used for treating epilepsy and as stupefying charm medicine. It is used to } \\
\text { prevent malaria. }\end{array}$ \\
\hline 27. & $\begin{array}{l}\text { Chlorophytum } \\
\text { variegatum } \\
\text { Chrvsanthemum }\end{array}$ & Liliaceae & - & Ornamental plant \\
\hline & & Asteraceae & Flower & $\begin{array}{l}\text { The leaves are used medicinally to cure influenza symptoms, liver and menstrual } \\
\text { disorders and have antiinflammatory and antispasmodic properties. }\end{array}$ \\
\hline 29. & C. odoratum & Asteraceae & Flower & $\begin{array}{l}\text { Flowers are used for antihypertensive, serotonin antagonist, anticancer, } \\
\text { antispasmodic, antioxidative and antimicrobial activities. It prevent cancer and } \\
\text { lower blood pressure as well as improve the digestive system in human. }\end{array}$ \\
\hline 30. & Clitoria ternatea & Fabaceae & Whole plant & $\begin{array}{l}\text { The herb is effective in curing fever and acts as asthma and bronchitis etc. A paste } \\
\text { of the whole plant can be applied over the infected area and decoction of the plants } \\
\text { is very effective in cleaning the wound. }\end{array}$ \\
\hline 31. & $\begin{array}{l}\text { Clerodendrum } \\
\text { thomsoniae }\end{array}$ & Verbenaceae & $\begin{array}{l}\text { Leaf and } \\
\text { flower }\end{array}$ & $\begin{array}{l}\text { Leaf aqueous extract is traditionally used by people to alleviate symptoms of } \\
\text { diabetics, obesity and hypertension. }\end{array}$ \\
\hline 32. & Coleus aromaticus & Lamiaceae & Leaf & $\begin{array}{l}\text { The leaves are used for the treatment of cough, throat infection and nasal } \\
\text { congestion. }\end{array}$ \\
\hline 33. & Cordyline stricta & Asparagaceae & Leaf & $\begin{array}{l}\text { It is used to treat dysentery and skin diseases. It breaks fever and headache. The } \\
\text { leaves consumed as greens. }\end{array}$ \\
\hline 34. & Cosmos bipinnatus & Asteraceae & $\begin{array}{l}\text { Flower and } \\
\text { leaf }\end{array}$ & $\begin{array}{l}\text { Leaves are used for fever, flue, cough, asthma, digestive troubles, piles, diabetics, } \\
\text { urinary diseases, male sexual diseases, gynecological diseases antiinflammatory, } \\
\text { ear diseases, skin diseases and miscellaneous uses. }\end{array}$ \\
\hline 35. & Crassula sp. & Crassulaceae & - & Ornamental plant \\
\hline 36. & $\begin{array}{l}\text { Crossandra } \\
\text { infundibuliformis }\end{array}$ & Acanthaceae & $\begin{array}{l}\text { Leaf and } \\
\text { latex }\end{array}$ & $\begin{array}{l}\text { In is used to treat infectious diseases while simultaneously mitigating many of the } \\
\text { side effects. }\end{array}$ \\
\hline 37. & Cucumis pepo & Cucurbitaceae & $\begin{array}{l}\text { Leaf, fruit } \\
\text { and seed }\end{array}$ & $\begin{array}{l}\text { Seeds are used as a diuretic. Leaves are used as a painkiller, a treatment for nausea, } \\
\text { and a boost to haemoglobin content of the blood. The fruit is used for cooling and } \\
\text { astringent to the bowels, increases appetite, cures leprosy and purifies the blood. } \\
\text { A fresh juice is commonly used in many skin conditions, including eczema, chicken }\end{array}$ \\
\hline 38. & Curcuma longa & Zingiberaceae & Rhizome & $\begin{array}{l}\text { pox, shingles, allergy, and scabies. The active compound curcumin have } \\
\text { antiinflammatory, antioxidant, antitumour and antiviral activities. }\end{array}$ \\
\hline 39. & Calotropis gigantea & Asclepiadaceae & Leaf and & The powdered root is used to treat bronchitis, asthma, leprosy, eczema, \\
\hline
\end{tabular}




\begin{tabular}{|c|c|c|c|c|}
\hline & & & latex & $\begin{array}{l}\text { elephantiasis while the latex is used to treat vertigo, baldness, hair loss, toothache, } \\
\text { intermittent fevers, rheumatoid/joint swellings and paralysis. }\end{array}$ \\
\hline 40. & Carica papaya & Caricaceae & $\begin{array}{l}\text { Leaf, fruit } \\
\text { and root }\end{array}$ & It increase appetite, ease menstrual pain, meat tenderizer and relieve nausea \\
\hline 41. & Coriandrum sativum & Apiaceae & $\begin{array}{l}\text { Seed, root } \\
\text { and leaf }\end{array}$ & $\begin{array}{l}\text { The seeds were included in a host of prescriptions for fever, diarrhoea, vomiting, } \\
\text { indigestion as in stomach and carminative. Leaves are given for biliousness, } \\
\text { intestinal irritations, heartburn, thirst and nausea. Volatile oil is carminative. }\end{array}$ \\
\hline 42. & $\begin{array}{l}\text { Cardiospermum } \\
\text { halicacabum }\end{array}$ & Sapindaceae & $\begin{array}{l}\text { Leaf and } \\
\text { fruit }\end{array}$ & $\begin{array}{l}\text { The tender shoots are used as a diuretic, stomachic and rubefacient. It is used in } \\
\text { rheumatism, lumbago, nervous diseases and as a demulcent in arthritis and in } \\
\text { dropsy. }\end{array}$ \\
\hline 43. & Cycas siamensis & Cycadaceae & - & Ornamental plant. \\
\hline 44. & Dracaena sp. & Asparagaceae & Fruit & The fruits are used in the treatment of malarial and kill intestinal worms. \\
\hline 45. & Duranta repens & Verbenaceae & $\begin{array}{l}\text { Leaf and } \\
\text { fruit }\end{array}$ & $\begin{array}{l}\text { The roots are stimulant for indolent ulcer. Different parts of the carrot have been } \\
\text { used in medicine for the treatment of kidney dysfunction, asthma, dropsy, } \\
\text { inflammation, leprosy etc. }\end{array}$ \\
\hline 46. & Damascus carota & Apiaceae & $\begin{array}{l}\text { Leaf and } \\
\text { latex }\end{array}$ & $\begin{array}{l}\text { The latex is used as a pain reliever, antibacterial agent, emetic and remedies for } \\
\text { skin warts and toothache. }\end{array}$ \\
\hline 47. & $\begin{array}{l}\text { Euphorbia } \\
\text { pulcherrima }\end{array}$ & Euphorbiaceae & $\begin{array}{l}\text { Leaf and } \\
\text { bark }\end{array}$ & $\begin{array}{l}\text { Decoction of the bracts and flowers are taken as galactagogue by nursing women to } \\
\text { increase milk flow. The leaves are applied as poultice and used as emeto cathartic } \\
\text { causing vomiting and bowel movement. }\end{array}$ \\
\hline 48. & Ficus benghalensis & Moraceae & Leaf & It is used for the treatment of skin diseases and enlargement of liver. \\
\hline 49. & F. benjamina & Moraceae & $\begin{array}{l}\text { Leaf, bark } \\
\text { and root }\end{array}$ & $\begin{array}{l}\text { It is used for the treatment of certain skin disorders, stomachic and antidysentery. } \\
\text { Leaf, bark and fruits are used as antiinflammatory, antinociceptive, antipyretic and } \\
\text { cytotoxic activity. }\end{array}$ \\
\hline 50. & F. microspora & Moraceae & $\begin{array}{l}\text { Leaf and } \\
\text { bark }\end{array}$ & $\begin{array}{l}\text { It has been used for intestinal problems, wounds and respiratory ailment. Oil is } \\
\text { considered a relaxant in aroma therapy. }\end{array}$ \\
\hline 51. & $\begin{array}{l}\text { Geranium } \\
\text { domesticum }\end{array}$ & Geraniaceae & $\begin{array}{l}\text { Seed and } \\
\quad \text { leaf }\end{array}$ & Ornamental plant \\
\hline 52. & Gomphrena globosa & Amaranthaceae & $\begin{array}{l}\text { Leaf and } \\
\text { flower }\end{array}$ & $\begin{array}{l}\text { It is used for bronchial asthma, acute and chronic bronchitis, chin cough, } \\
\text { haemoptysis of pulmonary tuberculosis, dizziness, blurring of vision, dysentery, } \\
\text { whooping cough and headache. }\end{array}$ \\
\hline 53. & Grevillea robusta & Proteaceae & - & Ornamental plant \\
\hline 54. & Hamelia patens & Rubiaceae & $\begin{array}{l}\text { Leaf and } \\
\text { flower }\end{array}$ & $\begin{array}{l}\text { It regulates menstruation and stimulate blood circulation. The flower extract has } \\
\text { been traditionally used for liver disorders, high blood pressure and as an } \\
\text { aphrodisiac. Young leaves and flowers are used in the case of headache. }\end{array}$ \\
\hline 55. & Hibiscus rosasinensis & Malvaceae & $\begin{array}{l}\text { Flower, root } \\
\text { and leaf }\end{array}$ & It is used in antiinflammatory and ingredients for cosmetics. \\
\hline 56. & H. syriacus & Malvaceae & Leaf and & It cures skin diseases. \\
\hline
\end{tabular}




\begin{tabular}{|c|c|c|c|c|}
\hline & & & flower & \\
\hline 57. & Inga cyanometroides & Fabaceae & Leaf & $\begin{array}{l}\text { It is used for hepatic disorder, cancer, microbial infection, antioxidant, pain and } \\
\text { inflammation. The flowers were used for the treatment of cancer, leucorrhoea, } \\
\text { dysentery, dysmenorrhoea, haemoptysis and hypertension. }\end{array}$ \\
\hline 58. & Ixora coccinea & Rubiaceae & $\begin{array}{l}\text { Leaf, root } \\
\text { and flower }\end{array}$ & $\begin{array}{l}\text { The leaves are used as an emetic in cases of poisoning. The roots are bitter, acrid } \\
\text { and are useful for external application in ringworm and herpes infestations and are } \\
\text { recommended for ophthalmopathy, ulcerative stomatitis, leprosy and wounds. }\end{array}$ \\
\hline 59. & $\begin{array}{l}\text { Jacquemontia } \\
\text { pentantha }\end{array}$ & Convolvulaceae & - & Ornamental plant \\
\hline 60. & $\begin{array}{l}\text { Jasminum } \\
\text { grandiflorum }\end{array}$ & Oleaceae & $\begin{array}{l}\text { Leaf and } \\
\text { root }\end{array}$ & Leaves are used in the treatment of leprosy, skin disease, ulcers, wounds and corns. \\
\hline 61. & J. sambac & Oleaceae & $\begin{array}{l}\text { Leaf, flower } \\
\text { and root }\end{array}$ & $\begin{array}{l}\text { The plant is used for cooling, skin disorders, leprosy, ulcers, in cases of insanity, } \\
\text { weakness of sight and affections of mouth and opium for gangrenous ulcers of the } \\
\text { gums. }\end{array}$ \\
\hline 62. & Kalanchoe fentchokoi & Rubiaceae & - & Ornamental plant \\
\hline 63. & Lablab purpureus & Fabaceae & Leaf & It has antioxidant, anticancer, antiviral and antiinflammatory activities. \\
\hline 64. & Lawsonia inermis & Myrtaceae & $\begin{array}{l}\text { Stem bark, } \\
\text { root and leaf }\end{array}$ & $\begin{array}{l}\text { It is used as a traditional medicine to treat varies ailments such as rheumatoid } \\
\text { arthritis, headache, ulcers, diarrhoea, leprosy fever, leucorrhoea, diabetics, } \\
\text { hepatoprotective and colouring agent. }\end{array}$ \\
\hline 65. & Mangifera indica & Anacardiaceae & $\begin{array}{l}\text { Fruit and } \\
\quad \text { leaf }\end{array}$ & $\begin{array}{l}\text { Fruit is proposed as nutritional supplement (antioxidant) and an anti- } \\
\text { inflammatory, analgesic and immunomodulatory treatment to prevent disease } \\
\text { progress or increase the patient's quality of life in gastric and dermatological } \\
\text { disorders, AIDS, cancer and asthma. Root bark is a bitter aromatic, and used for } \\
\text { diarrhoea and leucorrhea. }\end{array}$ \\
\hline 66. & $\begin{array}{l}\text { Miranda } \\
\text { leucophyllum }\end{array}$ & Scrophulariaceae & - & Ornamental plant. \\
\hline 67. & $\begin{array}{l}\text { Momordica } \\
\text { charantia }\end{array}$ & Cucurbitaceae & $\begin{array}{l}\text { Leaf, Fruit } \\
\text { and root }\end{array}$ & $\begin{array}{l}\text { Leaves are used for ulcers and as a bitter digestive aid for intestinal gas, bloating, } \\
\text { stomachache, and sluggish digestion. Fruit pulp, leaf juice and seeds are used for } \\
\text { antihelimintic. Leaf act as galactogogue and root is astringent. } \\
\text { Unripe bananas and plantain fruits are astringent and used to treat diarrhoea. The }\end{array}$ \\
\hline 68. & Moringa oleofera & Musaceae & Whole plant & $\begin{array}{l}\text { leaves are used for cough and bronchitis. The roots can arrest hemoptysis, strongly } \\
\text { astringent and anthelmintic properties. }\end{array}$ \\
\hline 69. & Nephrolepis sp. & Nephrolepidaceae & - & Ornamental plant. \\
\hline 70. & N. tuberosa & Nephrolepidaceae & Whole plant & $\begin{array}{l}\text { It is used as healing agents in inflammation, leucorrhoea, piles and as antidote. It } \\
\text { possesses antiviral, antibacteral, antiparasitic effects, anti-inflammatory, antiulcer } \\
\text { and antioxidant activity and used as diuretic. }\end{array}$ \\
\hline 71. & Nerium oleander & Apocynaceae & $\begin{array}{l}\text { Flower, leaf, } \\
\text { root and }\end{array}$ & $\begin{array}{l}\text { The flower used as blood purifier and also used in the treatment of jaundice of } \\
\text { diabetics, cancer, inflammation and eye disorders. }\end{array}$ \\
\hline
\end{tabular}




\begin{tabular}{|c|c|c|c|c|}
\hline & & & stem & \\
\hline 72. & Nymphaea pubescens & Nympheaceae & Leaf & Both the leaves and the essential oils are used for culinary and medicinal purpose. \\
\hline 73. & Ocimum basilicum & Lamiaceae & Leaf & It cures cold, cough. \\
\hline 74. & Plumbago auriculata & Plumbaginaceae & $\begin{array}{l}\text { Root and } \\
\text { leaf }\end{array}$ & $\begin{array}{l}\text { The latex has been used for the treatment of itches, swellings, fevers, } \\
\text { inflammations, arthritis and constipation. The root is used to cure abscesses, } \\
\text { dysentery, syphilis and cough. }\end{array}$ \\
\hline 75. & Plumeria rubra & Apocynaceae & $\begin{array}{l}\text { Root, bark } \\
\text { and latex }\end{array}$ & $\begin{array}{l}\text { The fruits are used in the treatment and prevention of cancer, cardiovascular } \\
\text { disease, diabetics, dental conditions, erectile dysfunction, bacterial infections, } \\
\text { antibiotic resistance and ultraviolet radiation induced skin damage. }\end{array}$ \\
\hline \multirow{2}{*}{$\begin{array}{l}76 . \\
77 .\end{array}$} & \multirow{2}{*}{$\begin{array}{l}\text { Piper betle } \\
\text { Ravenala } \\
\text { madagascariensis }\end{array}$} & Piperaceae & Leaf & It cures cold and cough. \\
\hline & & Strelitziaceae & Leaf & $\begin{array}{l}\text { Leaves are used for metrorrhagia, hemoptysis, large intestine hemorrhage, } \\
\text { rheumatic arthritis and gynecologic disease. }\end{array}$ \\
\hline 78. & Rosa sp. & Rosaceae & Flower & $\begin{array}{l}\text { It has been used for maintaining health, boosting immune system function, various } \\
\text { therapies and remission of cancer. }\end{array}$ \\
\hline 79. & Salvinia officinalis & Lamiaceae & Leaf & $\begin{array}{l}\text { The leaf sap is applied directly to sores, cuts and grazes and treatment for } \\
\text { abdominal pains, ear ache, diarrhoea and hemorrhoids. }\end{array}$ \\
\hline 80. & $\begin{array}{l}\text { Sansevieria } \\
\text { roxburghiana }\end{array}$ & Asparagaceae & Flower & $\begin{array}{l}\text { Paste of leaves can be applied to relieve pains. Seeds act as expectorant in cough } \\
\text { and asthma. The roots are expectorant and diuretic, useful in the treatment of } \\
\text { catarrhal fever, coughs, asthma and chest pain }\end{array}$ \\
\hline 81. & $\begin{array}{l}\text { Solanum } \\
\text { xanthocarpum }\end{array}$ & Solanaceae & $\begin{array}{l}\text { Leaf and } \\
\text { root }\end{array}$ & $\begin{array}{l}\text { They are used for inflammatory, antioxidant, anti-allergic, hepatoprotective, and } \\
\text { anticarcinogenic activities. }\end{array}$ \\
\hline 82. & S. melongena & Solanaceae & $\begin{array}{l}\text { Fruit and } \\
\quad \text { leaf }\end{array}$ & $\begin{array}{l}\text { Decoction of leaf is used to cure diabetics, leprosy, gonorrhea, cholera, bronchits, } \\
\text { dysentery asthenia and haemorrhoids. }\end{array}$ \\
\hline 83. & S. lycopersicum. & Solanaceae & Fruit & $\begin{array}{l}\text { It is used in women related problems, such as leucorrhoea, menorrhagia, } \\
\text { dysfunctional uterine bleeding and bleeding hemorrhoids. }\end{array}$ \\
\hline & Saraca indica & Caesalpiniaceae & Leaf & $\begin{array}{l}\text { It cures the diseases of eyes cold conjunctivitis, bleeding piles and bronchitis. } \\
\text { The essential oil within the plant has been used for cleaners, disinfectants, hair }\end{array}$ \\
\hline 85. & Thuja occidentalis & Cupressaceae & Leaf & $\begin{array}{l}\text { reparations, insecticides, liniment, room sprays and soft soaps. Twigs to make teas } \\
\text { and to relieve constipation and headache. It is externally applied tincture or } \\
\text { ointment for the treatment of warts and ringworms. }\end{array}$ \\
\hline \multirow{3}{*}{$\begin{array}{l}86 . \\
87 . \\
88 .\end{array}$} & Thunbergia erecta & Acanthaceae & - & Ornamental plant \\
\hline & T. mysorensis & Acanthaceae & - & Ornamental plant \\
\hline & $\begin{array}{l}\text { Tabernaemontana } \\
\text { divaricata }\end{array}$ & Apocynaceae & Leaf & Ornamental plant \\
\hline \multirow{2}{*}{$\begin{array}{l}89 . \\
90 .\end{array}$} & Taxus wallichiana & Taxaceae & $\begin{array}{l}\text { Leaf and } \\
\text { bark }\end{array}$ & $\begin{array}{l}\text { The stem bark is used as a anticancer. This species is also used as fuel wood by the } \\
\text { local communities. }\end{array}$ \\
\hline & $\begin{array}{l}\text { Zephyranthes } \\
\text { carinata }\end{array}$ & Amaryllidaceae & Flower & Ornamental plant \\
\hline
\end{tabular}



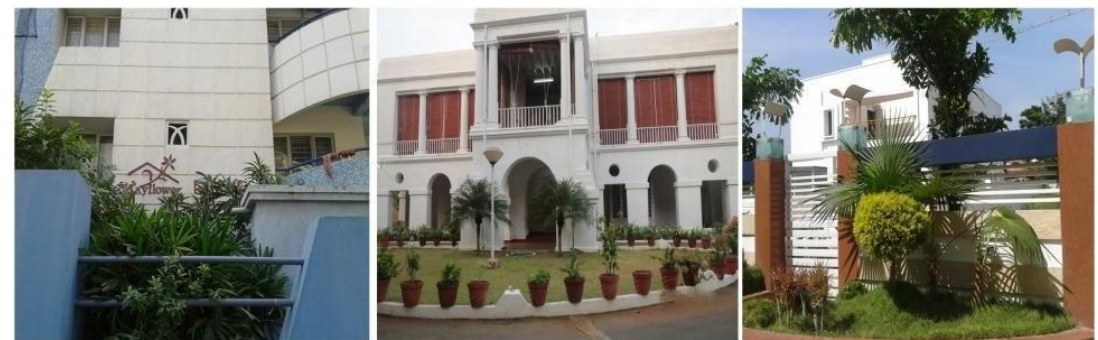

R.S. Puram

Race course
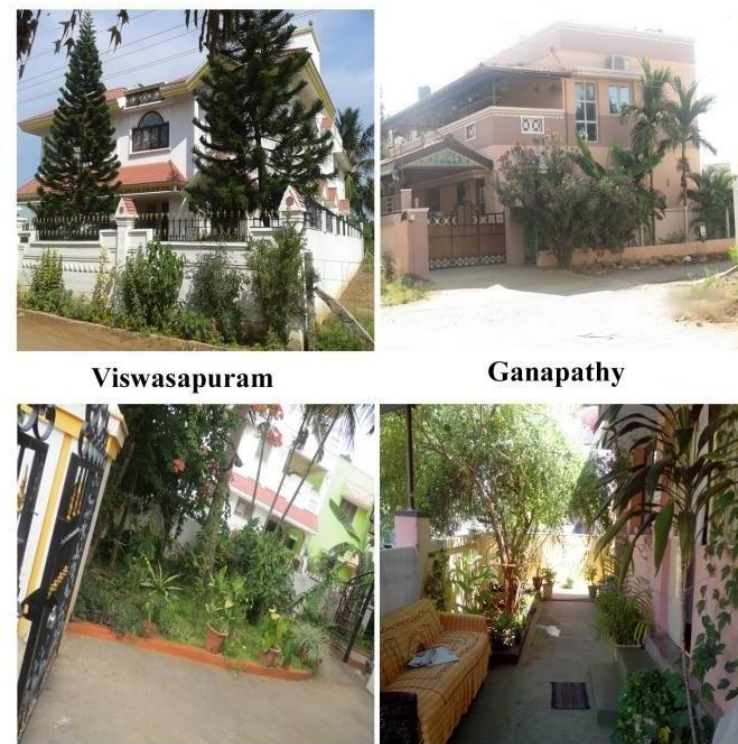

Maniyakarampalayam
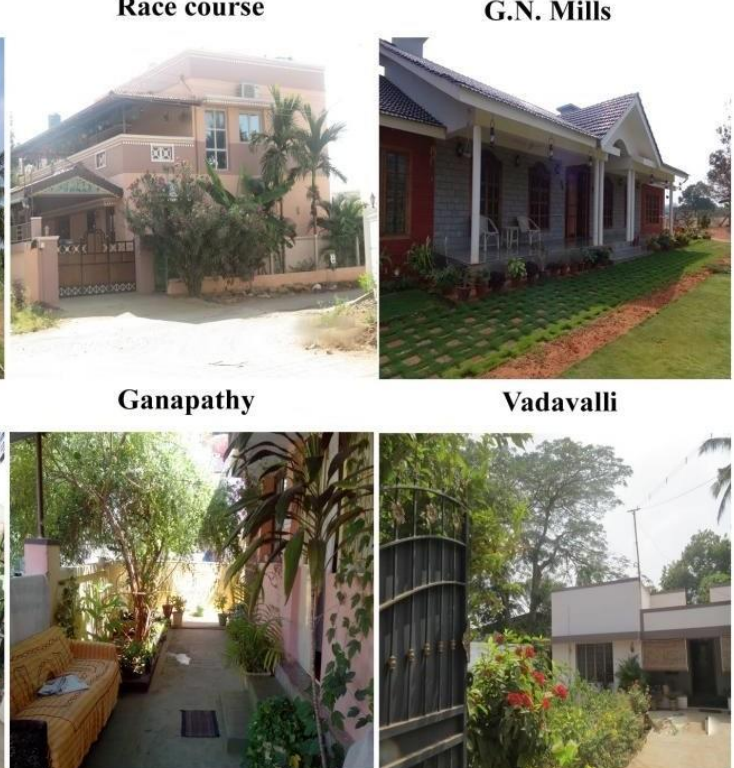

Vadavalli
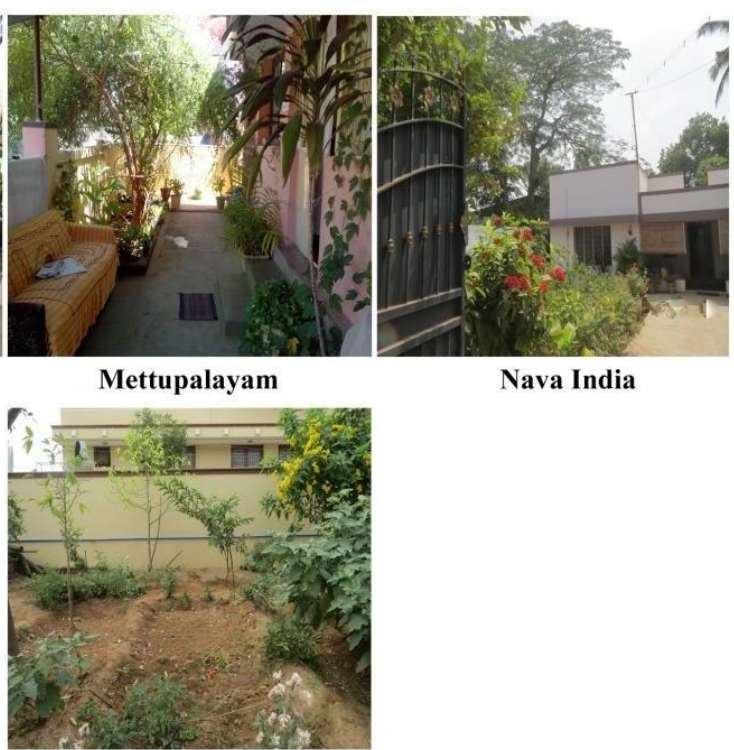

Saravanampatti

Fig. 1. The sampled home gardens of Coimbatore city.

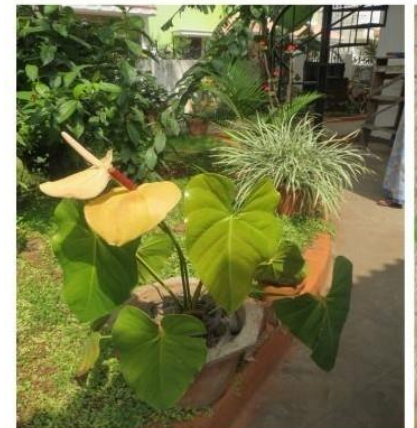

Anthurium spathiphyllum

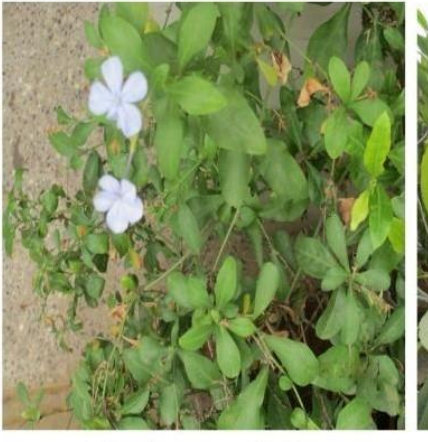

Plumbago auriculata

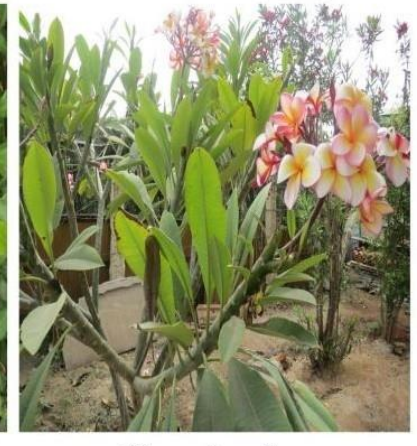

Plumeria rubra

Fig. 2. The species of higher degree of distribution among the home gardens.

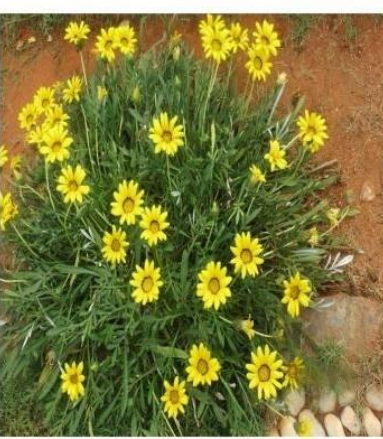

Argyranthemum frutescens

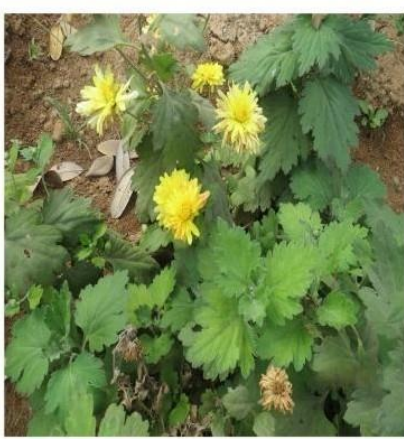

Chrysanthemum odoratum

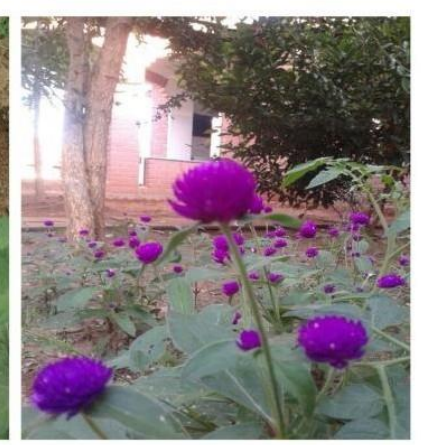

Gomphrena globosa

Fig. 3. Some species of relatively high density.

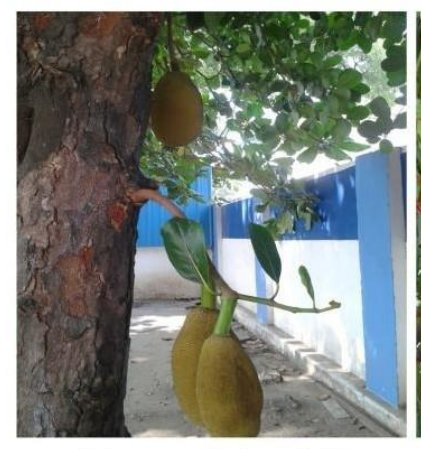

Artocarpus heterophyllus

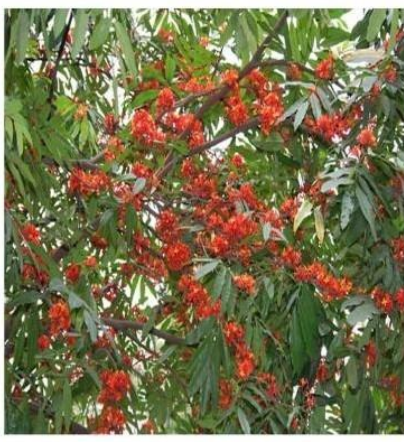

Saraca indica

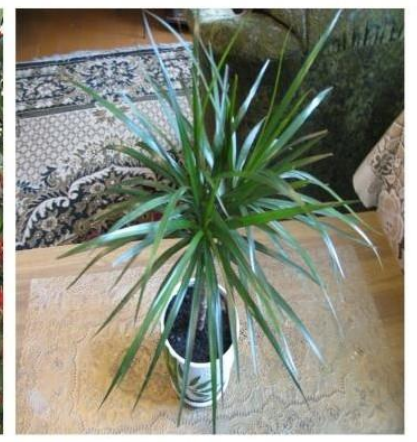

Dracaena sp.

Fig. 4. Certain species of relatively low density. 
Although, the proportion of species used for different purposes vary, in general traditional home gardens contribute sustainably towards meeting the basic subsistence needs of their owners for product and services such as food including vegetables and fruits, medicines, forage, shade and ornamental (Alburquerque et al., 2003). Presently many home gardens show a shift from subsistence oriented agriculture to market (Peyre et al., 2006).

The study concludes that the home garden ensure crop diversification, provide diversified products though low in amount but nutritious in nature, conserve plant genetic resources and evolutionary processes in the Coimbatore city.

\section{REFERENCES}

Abdoellah, O.S. (1990). Home gardens in the Java and their future development. In: K. Landaeurand and M. Brazil (eds.) Tropical Home gardens. United Nations University Press Tokyo, Japan, p. 69-79.

Abdoellah, O.S., Y. Hadiskushumah, K. Takeuchi, S. Okubo and Parikeist, (2006). Commercialization of home gardens in an Indonesia village: vegetation composition and functional changes. Agroforestry ecosystems 68:1-13.

Ahmedullah, M. and M.P. Nayar, (1987). Endemic plants of the Indian Region. Vol. 1. Botanical Survey of India, Howrah.

Alburquerque, U.P., L.H.C. Andradeb and J. Caballeroc, (2003). Structure and floristics of home garden in North eastern Brazil. J. Arid Environment. 62: 491-506.

Esquivel, M. and K. Hammer, (1992). The Cuban home garden Cunaco A perspective environment for evolution and in situ conservation of plant genetic resources. Genetic Res. Crop Evolut. 39: 9-22.

Fernandez, E.C.M. and P.K.R. Nair, (1986). An evaluation of the structure and functions of tropical Home gardens. Agroforest. Syst. 21: 279-310.

Gajaseni, J. and N. Gajaseni, (1999). Ecological rationalities of the traditional home garden system in the Chao phraya Basin, Thailand. Agroforest. Syst. 46: 3-23

Kabir, M.E. and E.L. Webb, (2008). House hold and homegardens characteristics in south western Bangladesh. Agroforest. Syst. 24: 203-213.

Kumar, B.M. and P.K. Nair, (2004). The enigma of tropical home gardens. Agroforest. Syst. 61:135152.

Kumar, B.M., S.J. George and S. Chinnamani, (1994). Diversity, structure and standing stock wood in the home gardens of Kerala Peninsular India. Agroforest. Syst. 25: 243-262.

Pandey, C.B., R.B. Rai, L. Singh and A.K. Singh, (2006). Home gardens of Anadaman and Nicobar, India. Agricultural Systems (in press).

Peyre, A., A. Guidal, K.F. Wiersum and F. Bongers, (2006). Dynamics of home garden. Structure and function in Kerala India. Agroforest. Syst. 66:101.

Rico Gray, V., A. Chemas and S. Mandujano, (1991). Uses of tropical deciduous forest species by the Yucataean Maya. Agroforest. Syst. 14: 149-161.

Shrestha, P., P.R. Gautham and B. Sthapthi, (2001). Home gardens in Nepal status and scope for research and development. In: Watson J.W. and P.B. Eyzagureie (eds). Home gardens and in situ conservation ofplant genetic resources in Farming systems. Proceedings of the Second International Home garden Workshop, WitzenHausen, Federal Republic of Germany, p. 105124.

Trinh, L.N., J.W. Watson, N.N. Hue, N.N. De, N.V. Minh, P. Chu, B.R. Sthapti and P.B. Ezyagurrie, (2003). Agrobiodiversity conservation and development in Vietnamse home gardens. Agric. Ecosyst. Environ. 97: 317-344. 